\title{
The health of women of reproductive age and their childhearing intentions
}

\author{
Monika Mynarska ${ }^{1}$, Wiktoria Wróblewska ${ }^{2}$
}

\begin{abstract}
${ }^{1}$ Instytut Psychologii, Uniwersytet Kardynała Stefana Wyszyńskiego w Warszawie; ${ }^{2}$ Instytut Statystyki i Demografii, Szkoła Główna Handlowa w Warszawie

Address for correspondence: Wiktoria Wróblewska, Instytut Statystyki i Demografii, Szkoła Główna Handlowa w Warszawie, 02-513 Warszawa, ul. Madalińskiego 6/8, phone 22564 92 70,wwrobl@sgh.waw.pl
\end{abstract}

\section{Abstract}

The aim of the analyses presented in this article is to examine the role of health in women's childbearing choices in Poland. Data from the "Generation and Gender Survey" (GGS-PL) are used. The first wave of this panel survey was carried out in Poland in late 2010 and early 2011. Four different indicators of health are used in the analyses to verify whether women with disabilities or experiencing various health problems limit their parental plans. The results suggest that each health aspect may be relevant for predicting the women's intention to have a child within the next three years. However, the multivariate analyses show that only women's self-rated health remains significant, if age, parity and marital status are controlled in the model.

\section{Key words: childhearing intentions, Generations and Gender Survey (GGS-PL), health, self-rated health \\ Slowa kluczowe: Generations and Gender Survey (GGS-PL), intencje rodzicielskie, Samoocena zdrowia, zurowie}

\section{Introduction}

'Fertility intentions' has become an increasingly attractive subject for researchers who wish to understand people's childbearing choices. Even though not all pregnancies are carefully planned and not all fertility plans realized, the intention to have a child stands as a good predictor of reproductive behaviour - especially if the intention is formulated within a relatively short time horizon and with a high degree of certainty [1-4]. Consequently, studies on fertility intentions offer valuable information on the factors and circumstances that encourage or discourage childbearing. They allow for identification of the conditions deemed necessary for having children and the factors that might prevent individuals from reaching parenthood.

Indeed, the number of studies on determinants of fertility intention around the world have been growing in recent years [5-9], and also in Poland [10, 11]. All these studies have brought together a vast body of evidence on, for example, how fertility choices are shaped by econo- mic factors such as level of education, financial and housing situation, employment status and job characteristics [9, 11-14]. Researchers have also investigated the role of norms, values and attitudes to fertility planning, by including such variables as religiosity, family-orientations or gender-role attitudes in their models [5, 8, 11, 14-17]. However, so far surprisingly little attention has been paid to the role of health in people's childbearing plans.

As people develop intentions, they assess their resources, abilities and opportunities. Intention is formulated only if a person believes that he or she has all necessary means to achieve a given goal $[18,19]$. In other words, when a person's perceived behavioural control (subjectively-assessed control over one's own behaviour) is sufficient [18]. Clearly, health is highly important in the perception of behavioural control. It is one of the most basic resources in bearing and raising children. It is not only about reproductive health, but about general health too. A woman who has had a hysterectomy will not think about becoming pregnant (although she might think about adopting a child, of course). Similarly, a woman, 
who suffers from a painful, chronic illness, might not feel fit for childbearing and will not intend to become a mother either. Indeed, in the Population Policy Acceptance Survey, conducted in 2001 in several European countries, $40 \%$ of childless women and $26 \%$ of childless men who did not intend to have a child (or were uncertain) indicated that their health was an important reason for this [20].

Even though health seems fundamental to fertility - especially for women - our knowledge of the relationship between health and childbearing intentions is astonishingly limited, and this relationship is rarely a focal point of research. There are numerous studies on the fertility intentions of people living with HIV [21-23] or with other chronic diseases, such as cystic fibrosis [24]. These studies, however, focus predominantly on populations with a diagnosed health problem, and on the special needs - related to childbearing - of individuals with chronic conditions.

Of course, there are some studies that offer interesting insights into the topic. Recent research by Shandra and colleagues [25] shed light on how disability plays a role in fertility intentions. The authors showed that compared to mothers without disabilities, those with disabilities were more likely to want, but less likely to intend to have, another child. In line with our own theoretical considerations, these findings indicate that disability constitutes an important element of perceived behavioural control, discouraging fertility intentions even if a child is highly desired. Surprisingly, this finding was not confirmed for childless women. In contrast, another study in which health status was introduced as a background variable [8], indicated that self-rated health is important in the fertility intentions of childless women, but not in the intentions of mothers. Importantly, the direction of the relationship between health and intention was unexpected: compared to individuals without any health problems, those with self-reported bad health or serious illness were more likely to want a child right away than within the next three years [8, p. 51]. The authors speculated that women experiencing health issues could feel urged into motherhood, intending to have a child before their condition worsened.

The scarcity of research and the aforementioned contradictions in the findings clearly show a need for further study of the significance of health in fertility intentions. This topic is also particularly relevant in Poland. Even though Polish women's health has been continuously improving over the last 25 years, it is still poorer in Poland than in most European countries, especially among women of reproductive age [26].

Polish women live longer and are healthier than they used to be. Their mortality rates have been declining and their life expectancy at birth has meaningfully increased: from 75.3 in 1990 to 81.7 in 2014 (Eurostat database). Nevertheless, women's life expectancy in Poland remains lower than the EU average (83.6 in 2014, Eurostat database). European health studies (European Health Interview Surveys - EHIS - 2009, 2014) and Health Surveys $(1996,2004)$ carried out in Poland by its Central Statis- tical Office show an improvement in self-rated health, disabilities, longstanding health problems and chronic conditions among Polish women [27-30]. Currently, in Poland, a percentage of women (aged 15 or more) with some level of disability is only slightly higher at $21 \%$ than the EU average of $20 \%$ (Eurostat, EHSIS data 2011). Similarly, the percentage of Polish women experiencing difficulties with basic daily activities is equal to the EU average of $15 \%$ (Eurostat, LFS data 2012). However, analyses conducted by Wojtyniak [26] showed that in Poland, mortality among women aged 15-49 remains higher and women die of cancer (especially cervical cancer) and cardiovascular diseases more often than in most EU countries. Only the Baltic states and Hungary have similarly poor, or even poorer, rates [26].

Another study, conducted in Poland in 2005, showed that the health problems experienced by women of reproductive age have a negative impact on various spheres of their lives [31]. In the survey, $12.6 \%$ of women aged $18-24$ and $16.8 \%$ of women aged $25-44$ declared that their health problems have led to difficulties with performing their household duties. Their poor health has also had a negative impact on their contact with family (declared by approximately $13 \%$ of women in both age groups), and on their intimate contact with their partners (declared by $8.3 \%$ of women aged $18-24$ and $13 \%$ of women aged 25-44) [31].

The data presented above indicates that a noteworthy percentage of Polish women of reproductive ages might experience some limitations related to their health. Additionally, a recent study in Poland suggested that for approximately $10 \%$ of childless women aged $37-45$, health problems might constitute the main reason for their having no offspring [32]. It is against this background that we sought to understand the role of health in the fertility choices of women in Poland. We will characterise the health status of women of reproductive age based on the first wave of the Generations and Gender Survey [33], which was conducted in Poland in 2010/2011. This rich source of data will allow us to answer our main research question: How important is women's health in their childbearing intentions?

\section{Data and methods}

For our analyses, we used data from the first round of the Generations and Gender Survey (GGS-PL1), conducted in Poland at the turn of 2010 and 2011. The survey was conducted as a part of the Generations and Gender Programme (GGP) international research programme on a random, nationally representative sample of almost 20,000 Poles aged 18-79. It yielded detailed data on their characteristics, life histories, intentions and attitudes [34]. Amongst other things, the respondents were asked to provide information on the status of their health. Individuals in reproductive age were additionally asked about their (short-term) childbearing intentions. These questions were crucial for our research question.

For our analytical sample, we included all women aged $20-44$ at the time of the survey $(n=4224)$. Even 
though reproductive age is usually defined as being from 18 to 49 , we decided to exclude the youngest and oldest. Birth rates are very low for women under 20 and for those over 44, and childbearing intentions are formulated extremely rarely in these age groups [35]. Furthermore, whenever educational level is included in our analyses, surveys on the topic are conducted for women aged 25-44.

The GGS-PL1 included several questions that assess the respondents' health, and we considered four of them. The first of these is a question on self-rated health: "How is your health in general?", answered on a scale from 1 (very good) to 5 (very bad). This question aims to capture overall, subjective, health status. The second question concerns longstanding health problems: "Do you have any long-standing illness or chronic condition (such as asthma, arthritis or diabetes)?'. Respondents could answer 'Yes' or 'No'. The third question deals with health-related limitations in daily activities: "Are you limited in your ability to carry out normal everyday activities, because of a health problem or disability?". Again, only 'Yes' or 'No' answers were possible. The fourth survey question we considered dealt with the respondents' disabilities. Each respondent was asked to declare whether they are disabled ('Yes' or 'No'), regardless of whether they had been officially certified as such.

We use these four questions to characterise the health status of women of reproductive age, and as predictors of childbearing intentions.

The GGS also poses a question on short-term childbearing intentions: "Do you intend to have a/another child during the next three years?". Respondents were asked not to include plans to adopt or foster a child, and could then choose from four answers: 1 -definitely not, 2 - probably not, 3 - probably yes, 4 - definitely yes. In our analyses, we merged the positive and negative answers together. Consequently, each woman was assigned to one category: "Intends to have a child in the next three years", or "Does not intend to have a child in the next three years".

We also considered several demographic characteristics in our analyses: age, number of children, marital status and educational level. Previous studies indicated that these characteristics are significant in women's childbearing plans (independently of their health). As such, we included them in our analyses of childbearing intentions as control variables. Moreover, women's health status (selected indicators) is presented for all women of reproductive age, and also for other age categories (20-24; 25-29; 30-34; 35-39; 40-44), since age is a primary determinant of health.

In this paper, we will present some of our descriptive findings and describe the health of women of reproductive age in Poland, to give some background to our analyses. Next, we will focus on the relationship between health and fertility intentions. In the initial exploration, we will look at how women, who declare different childbearing intentions, differ in their health status, as measured by all four indicators. A chi-square statistic is used in these comparisons.
Finally, we run a multivariate model to answer our research question and explain how women's health status shapes their fertility intentions. To this end, we perform a logistic regression analysis ${ }^{1}$ and predict women's fertility intentions (dependent variable Y) as a function of different indicators of their health, controlling for age, marital status and parity. For the estimated models, odds ratio (OR) will be given to illustrate the relationships between the variables. The odds ratio is the ratio of the probability of the occurrence of the event under analysis, divided by the probability of the non-occurrence of the event. If the occurrence of a given category of an explanatory variable $(\mathrm{X})$ is connected with a higher risk of the occurrence of the event under analysis $(\mathrm{Y}=1)$, when compared with the reference category of variable $\mathrm{X}$, then OR is higher than 1.

All calculations were performed using the IBM SPSS Statistics v. 23.

\section{Results}

\section{The health of Polish women of reproductive age (20-44)}

Among women of reproductive age (20-44), almost $20 \%$ evaluated their health as less than good (fair, bad or very bad). Not surprisingly, this percentage increases with age. In the 20-24 group, one woman in ten was not satisfied with her health; in the 35-39 group it was one in four. When women aged 40-44 are considered, almost one third declared that their health was fair or worse (Table I). Furthermore, a notable percentage of women reported longstanding health problems or chronic condition. Among women aged 20-34, approximately 10\% suffered from such enduring illnesses. Among women aged 35 or more, the percentage of women with longterm health problems increased remarkably and at the age of 40-44 one woman in four reported such a condition.

Disability (self-reported, though not necessarily legally certified), affected nearly $4 \%$ of women of reproductive age in the analysed sample. Among women aged 20-24, two in 100 declared themselves disabled, while among those aged 25-39, this figure was nearly 4 in 100 . Disabilities can include limited ability to carry out normal, everyday activities. However, the incidence of such limitations was almost twice lower than the prevalence of disability (Table I).

Not surprisingly, the analysed health indicators were closely related to each other. Negative assessments of own health coincided with declarations of disability and other health problems. In fact, $70 \%$ of women declaring disability, $65 \%$ of women with longstanding health problems and $85 \%$ with a limited ability to carry out normal everyday activities rated their health as less than good. Nonetheless, disability or longstanding illness was not always linked with poor self-rated health, and those with poor health were not necessarily disabled or suffering from a chronic condition. Therefore, as we analyse the relationship between health and fertility intentions, all four health indicators will be considered independently. 


\begin{tabular}{|c|c|c|c|c|c|c|c|}
\hline & & \multicolumn{5}{|c|}{ Age group } & \multirow{2}{*}{ Total } \\
\hline & & $20-24$ & 25-29 & $30-34$ & 35-39 & $40-44$ & \\
\hline \multirow[t]{4}{*}{ Self-rated health } & Very good & 40,5 & 31,7 & 26,2 & 17,6 & 11,3 & 25,2 \\
\hline & Good & 47,3 & 53,4 & 58,8 & 56,6 & 56,3 & 54,9 \\
\hline & Fair & 11,9 & 13,2 & 13,4 & 22,2 & 27,3 & 17,5 \\
\hline & Bad or very bad & 0,3 & 1,7 & 1,6 & 3,6 & 5,0 & 2,4 \\
\hline \multirow{2}{*}{$\begin{array}{l}\text { Longstanding illness or } \\
\text { chronic condition }\end{array}$} & Yes & 9,6 & 12,8 & 10,2 & 17,6 & 25,4 & 14,9 \\
\hline & No & 90,4 & 87,2 & 89,8 & 82,4 & 74,6 & 85,1 \\
\hline \multirow{2}{*}{$\begin{array}{l}\text { Limited ability to carry out } \\
\text { normal everyday activities }\end{array}$} & Yes & 0,8 & 1,6 & 1,0 & 2,7 & 4,9 & 2,1 \\
\hline & No & 99,2 & 98,4 & 99,0 & 97,3 & 95,1 & 97,9 \\
\hline \multirow[t]{2}{*}{ Disability } & Yes & 2,0 & 3,8 & 3,6 & 3,9 & 6,4 & 3,9 \\
\hline & No & 98,0 & 96,2 & 96,4 & 96,1 & 93,6 & 96,1 \\
\hline
\end{tabular}

Table I. Health status of women, selected indicators. Percentages in each age group and for all women aged 20-44.

Source: Own calculations on the basis of GGS-PL1 data.

\section{Reproductive intentions and health - descriptive statistics}

In the analysed sample, almost $30 \%$ of women aged 20-44 intended to have a child within the next three years. The descriptive analyses indicate that the percentage of these women varied meaningfully between different health status categories, in respect to all considered health indicators. The greatest differences occurred with respect to self-rated health (Table II). Among women who rated their health as good or very good, as many as $36 \%$ intended to have a child in the near future. Among those who described their health as bad or very bad, only one respondent in ten declared such intentions. For other health indicators, the results show a similar pattern: 78\% of women with longstanding health problems, $82 \%$ of women with limited ability to carry out daily activities, and $79 \%$ of disabled women did not plan to have any children.
Before we present the multivariate model, we shall briefly consider how fertility intentions differed depending on women's age and other demographic characteristics that will be included in our models as control variables (Table III). The highest percentage of women intending to have a child was found in the 25-29 age group (almost half of the women of that age planned to have a child in the next three years). Not surprisingly, childbearing intentions were rare among older women in our sample, although among those aged 35-39, a child was still being planned for by $13 \%$. In the oldest age group, this dropped to just $4 \%$.

Among childless women of reproductive age, almost half declared plans to have a child in the next three years. This intention was lower among mothers of one child (40\%), and only one woman in ten was planning another child if she was already was a mother of two or more. In contrast, it might seem surprising that fertility

\begin{tabular}{|l|l|l|l|}
\hline \multirow{2}{*}{\multicolumn{2}{|l|}{}} & \multicolumn{2}{|c|}{ Intention to have a child during the next three years } \\
\cline { 3 - 4 } \multicolumn{2}{|c|}{} & \multicolumn{1}{|c|}{ Yes } & 71,3 \\
\hline \multirow{2}{*}{ Total: } & Very good & 28,7 & 63,7 \\
\cline { 2 - 4 } & Good & 36,3 & 71,0 \\
\cline { 2 - 4 } & Fair & 29,0 & 80,2 \\
\cline { 2 - 4 } & Bad or very bad & 19,8 & 89,3 \\
\hline \multirow{2}{*}{ Longstanding illness or chronic condition** } & Yes & 10,7 & 77,7 \\
\cline { 2 - 4 } & No & 22,3 & 70,1 \\
\hline \multirow{2}{*}{ Limited ability to carry out normal everyday activities** } & Yes & 29,9 & 81,8 \\
\cline { 2 - 4 } & No & 18,2 & 71,0 \\
\hline \multirow{2}{*}{ Disability* } & Yes & 29,0 & 79,0 \\
\cline { 2 - 4 } & No & 21,0 & 70,9 \\
\hline
\end{tabular}

$* p<0.05, * * p<0.001$.

Table II. Childbearing intentions by health status, women aged 20-44.

Source: Own calculations on the basis of GGS-PL1 data. 


\begin{tabular}{|c|c|c|c|}
\hline & & \multicolumn{2}{|c|}{ Intention to have a child during the next three years } \\
\hline & & Yes & No \\
\hline \multicolumn{2}{|l|}{ Total } & 28,7 & 71,3 \\
\hline \multirow[t]{5}{*}{ Age group* } & $20-24$ & 40,1 & 59,9 \\
\hline & $25-29$ & 49,4 & 50,6 \\
\hline & $30-34$ & 36,1 & 63,9 \\
\hline & $35-39$ & 13,0 & 87,0 \\
\hline & $40-44$ & 3,9 & 96,1 \\
\hline \multirow[t]{3}{*}{ Marital status* } & Single & 38,0 & 62,0 \\
\hline & Married & 26,2 & 73,8 \\
\hline & Other (widowed, divorced, separated) & 16,2 & 83,8 \\
\hline \multirow[t]{3}{*}{ Number of children* } & Childless & 47,0 & 53,0 \\
\hline & 1 child & 38,6 & 61,4 \\
\hline & 2 or more children & 11,4 & 88,6 \\
\hline \multirow[t]{3}{*}{ Level of education ${ }^{a}$} & Post-secondary or tertiary & 43,1 & 56,9 \\
\hline & Secondary & 28,6 & 71,4 \\
\hline & Vocational or lower & 17,8 & 82,2 \\
\hline
\end{tabular}

${ }^{a}$ only women aged $25-44, * p<0.001$.

Table III. Childbearing intentions by age, marital status, number of children and education (control variables), women aged 20-44.

Source: Own calculations on the basis of GGS-PL1 data.

intentions were declared among single women more often than among married ones. To understand this finding, it is necessary to consider marital status along with age and parity. This will be done in a multivariate model, in the next step.

Finally, women with post-secondary or tertiary education intended to have a child more often than their less educated counterparts. Since we look at women aged 2544 in this case, it is possible that women with secondary or lower degrees had at least realised some of their fertility plans by that age. But this result is also in line with other analyses of the Polish GGS data, which showed that childbearing intentions are higher among women with a tertiary education [11].

\section{Childhearing intentions and health - mullivariate model}

In our multivariate models, we predicted women's intentions as a function of different indicators of their health, controlling for basic demographic characteristics. As our goal is to verify whether health problems discourage childbearing intentions, our dependant variable (Y) is coded to equal 1 if a woman does not intend to have a child. Consequently, an odds ratio higher than 1 indicates that in a given category of an explanatory variable (relative to the reference category), a woman's childbearing plans are limited - in this respect, she is more likely to say 'No' to the question about her intentions.

In the first step, we examined the significance of health problems in childbearing intentions, without controlling for any characteristics of women (Model 1), and controlling for age only (Model 2). These first analyses were conducted to establish whether explaining women's fertility plans based on all four indicators of health problems is justified. The results are presented in Table IV below.

The results of Model 1 indicate that health problems can indeed limit women's fertility intentions and that the effect is significant for all used indicators. Women who rated their health as less than good and those with a limited ability to carry out daily activities were almost twice as likely to declare that they did not intend to have a child than women who did not experience any health problems. For those with longstanding illness or disability, the probability of not planning a child soon was approximately $50 \%$ greater, compared to their healthy counterparts. However, when age was introduced into the model, odds ratios decreased for all health indicators and were no longer significant for two of them: disability and limitations in everyday activities.

Nevertheless, even if we control for age, poor selfrated health and longstanding illnesses or chronic conditions retain a significant, limiting effect on women's childbearing intentions. Women who rated their health as less than good were $50 \%$ more likely to declare that they did not plan to have a child in the next three years, than women who said their health was good or very good. The respective probability increased $20 \%$ in cases of longstanding illness. Therefore, in the next step, we estimated models of fertility intentions for these two health indicators, controlling for a larger set of characteristics. First, we included age, number of children and marital status. These models are presented in Table $\mathbf{V}$. 


\begin{tabular}{|c|c|c|c|c|}
\hline & \multicolumn{4}{|c|}{ Health status variables } \\
\hline & $\begin{array}{l}\text { Self-rated health } \\
- \text { less than good }\end{array}$ & $\begin{array}{c}\text { Longstanding health } \\
\text { problems or chronic } \\
\text { condition }- \text { yes }^{\mathbf{b}}\end{array}$ & Disability - yes $^{\mathrm{c}}$ & $\begin{array}{c}\text { Limited ability to carry } \\
\text { out normal everyday } \\
\text { activities }- \text { yes }^{\mathrm{d}}\end{array}$ \\
\hline Model (1) & $1,983 * * *$ & $1,485 * * *$ & $1,548^{* *}$ & $1,838^{* *}$ \\
\hline $\begin{array}{l}\text { Model (2) } \\
\text { Controlled for age }\end{array}$ & $1,516 * * *$ & $1,194 *$ & 1,312 & 1,309 \\
\hline
\end{tabular}

${ }^{a}$ reference category - good or very good health, ${ }^{b}$ ref-no longstanding illnesses or chronic conditions, ${ }^{c}$ ref-no disabled, ${ }^{d}$ ref-no limitations on everyday activities.

$* p<0.1, * * * p<0.001$.

Table IV. Odds ratios from logistic regression models showing the effects of women's health in their reproductive intentions, uncontrolled (Model 1), and controlled for age (Model 2) on their intention to have a child in the next three years (women aged 20-44). Source: Own calculations on the basis of GGS-PL1 data.

\begin{tabular}{|l|c|c|}
\hline \multicolumn{1}{|c|}{ Health status } & Model 3 & Model 4 \\
\hline $\begin{array}{l}\text { Self-rated health - less than good } \\
\text { (reference: good or very good) }\end{array}$ & $1.394^{*}$ & 1.189 \\
\hline $\begin{array}{l}\text { Longstanding health problems or chronic condition } \\
\text { (reference: no) }\end{array}$ & - & $1.103^{* *}$ \\
\hline Age & $1.101^{* *}$ & \\
\hline $\begin{array}{l}\text { Number of children } \\
\text { (reference: childless) }\end{array}$ & & $1.351^{*}$ \\
\hline One child & & $5.694^{* *}$ \\
\hline Two or more children & $1.349^{*}$ & \\
\hline $\begin{array}{l}\text { Marital status } \\
\text { (reference: married) }\end{array}$ & $5.628^{* *}$ & \\
\hline Single & & $2.155^{* *}$ \\
\hline Other (divorced, separated, widowed) & $2.148^{* *}$ & $1.410^{*}$ \\
\hline Constant & $1.385^{*}$ & $0.043^{* *}$ \\
\hline
\end{tabular}

$* p<0.01, * * p<0.001$.

Table V. Odds ratios from logistic regression models showing the effects of self-rated health (less than good, Model 3) and longstanding health problems or chronic conditions (Model 4) on the intention to have a child during the next three years (women aged 20-44).

Source: Own calculations on the basis of GGS-PL1 data.

The estimated Model 3 shows that for women aged $20-44$, self-rated health can indeed play a limiting role in their childbearing choices - age independent of their age, marital status and parity. If a woman rated her health as less than good, the probability of her not intending to have a child was almost $40 \%$ higher than of a woman who was satisfied with her physical condition.

As for the control variables, their role, as depicted in the descriptive statistics (Table III), has been confirmed here, with the exception of marital status. The multivariate results show that if age and number of children are controlled for, single, divorced, separated or widowed women were more likely to say 'No' to the question about their childbearing plans. To disentangle the role of marital status, we estimated the same model separately for both younger and older women (20-34 versus 35-44).
Being single had a limiting effect on fertility intentions for younger women, but the opposite was true for older women. This might indicate that among those aged over 34 , married women have already realised most of their fertility plans, and those who have not started their own family yet are strongly determined to do so. This gives a better insight into the relationship between women's age, marital status and fertility intentions, and explains the discrepancy between our descriptive (Table III) and multivariate (Table V) results. The detailed results of these analyses are available from the authors upon request.

Noteworthy, all estimations of Model 4 are closely in line with those of Model 3. However, the role of health as indicated by longstanding health problems or chronic conditions - was insignificant. Longstanding health prob- 
lems significantly limited women's fertility intentions if parity was not controlled for (odds ratio $=1.2$ ). It seems that the role of this indicator should not be disregarded, but investigated more closely in future studies.

Before we conclude, it is necessary to comment on the role of education. Since education was included only for women aged 25-40, we did not control for this characteristic in the models presented in Table V. However, the specified models were additionally estimated separately for two educational groups: women with post-secondary or higher education, and those with a secondary or lower education. These results are not shown here, but are also available from the authors upon request. Interestingly, self-rated health and longstanding health problems had a significant, limiting effect on fertility intentions only for women with a maximum secondary education. The effects were insignificant for those with post-secondary or tertiary education. There could be several reasons for the insignificant findings of the better-educated respondents. First, well-educated women aged 25 are usually childless, so their fertility plans are still unrealised and they might be strongly determined to have children during the next few years. Second, the selection effect related to health should not be overlooked here. Poor health may prevent people from completing higher levels of education [37-39], leading to a selection of individuals characterised by particularly severe (long-lasting) health problems to the less-educated categories.

\section{Summary and conclusions}

The main aim of our paper was to investigate the significance of women's health in their childbearing intentions. We wanted to verify whether women who are disabled or experiencing health problems were more likely to limit their plans regarding parenthood. In our analyses, we used four different indicators of health status. The results suggested that all four might be important in childbearing intentions, although only women's self-rated health was consistently significant at all stages of our analyses. Even if other variables were considered in the model, such as age, marital status or number of existing children, self-rated health remained a statistically significant factor in women's fertility choices.

The limiting role of self-assessed health in women's childbearing plans is worrying. Since this effect remained significant regardless of age, it can be seen that even some young women put off their childbearing plans due to unsatisfactory health. At the same time, the analysed data showed that a meaningful percentage of women of reproductive age assessed their condition as less than good. Already among women aged 25-34, 15\% were unsatisfied with their health. Importantly, this is the age range when most fertility choices are made in contemporary Poland [40]. If we consider that health declines sharply with age, and at the same time that Polish women continue to have offspring later and later in life (ibid), then health might play an increasingly important role in women's future childbearing decisions, having a limiting effect on their fertility. This is a highly important con- clusion. Typically, when age and fertility are considered, researchers focus on reproductive health and declining fecundity $[41,42]$. Our results suggest that general health is also significant.

In our study, the most subjective indicator of selfrated health was more important in women's childbearing plans than those reflecting more objective symptoms (disability, longstanding health problems, chronic conditions, limitations in everyday activities). In line with Ajzen's model [18], a subjective evaluation of available resources and opportunities is crucial for any intention. Our results confirm that a woman's perception of her own health plays an important role in her intentions to have a child. If a woman fears that her health is not good enough, she will not plan to become a mother. The focus on subjective perceptions supports Ajzen's theoretical approach, and helps to clarify how health can impact childbearing intentions without the mediating effects of education, employment or other variables.

Importantly, it also highlights a wider, bio-psychosocial approach to health. Health considered from this perspective should be understood as a range of physical, mental and social capacities needed to perform well in all life-spheres, including taking on certain social and familial roles [43]. This wider approach is also in line with the definition of health coined by the WHO: Health is a state of complete physical, mental and social well-being and not merely the absence of disease or infirmity [44]. It is not only about a lack of symptoms, but about whether a person feels fit for various activities and life choices.

Given that health is highly important in all lifespheres, we found it surprising that so far, relatively little attention had been paid to its relationship to childbearing intentions. However, the paramount role of health makes it challenging to investigate this relationship. Health status is related to age, but is also linked with education, employment and material status. It can influence an individual's choices of partner, too. All these factors have been found to be significant in people's childbearing intentions in previous research $[9,11-14]$. Health status could have been an uncontrolled cofounder in these studies, so it is highly important to understand how health is intertwined with other factors, and to disentangle its direct and indirect effects on fertility choices. Further studies are called for in this direction. Ultimately, in future research, the role of health should not be overlooked, but should be considered along with other determinants of childbearing intentions, and from a cross-national perspective.

\section{Acknowledgments}

The research presented in this article was funded by the National Science Centre (Poland), under grant number 2013/08/M/HS4/00421. The analysed data was collected as part of research project 554/N-UNECE/2009/0, also funded by the National Science Centre (Poland). 


\section{Note}

1 The description of the method, including the formulas applied to estimating the parameters of the model, can be found in Hosmer, Lemeshow [36].

\section{References}

1. Kapitány B., Spéder Z., Realization, postponement or abandonment of childbearing intentions in four European countries, "Population" 2012; 67 (4): 599-629.

2. Schoen R., Astone N.M., Kim Y.J., Nathanson C.A., Fields J.M., Do fertility intentions affect fertility behavior?, "Journal of Marriage and Family" 1999; 61 (3): 790-799.

3. Spéder Z., Kapitány B., How are time-dependent childbearing intentions realized? Realization, postponement, abandonment, bringing forward, "European Journal of Population" 2009; 25 (4): 503-523.

4. Vinokur-Kaplan D., To have - or not to have - another child: Family planning attitudes, intentions, and behavior, "Journal of Applied Social Psychology" 1978; 8 (1): 29-46.

5. Bernardi L., Ryser V.-A., Le Goff J.-M., Gender role-set, family orientations, and women's fertility intentions in Switzerland, "Partnerschaftliche Rollenaufleitung, Familienorientierung und Kinderwunsch von Frauen in der Schweiz" 2013, 39 (1): 9-31.

6. Billari F.C., Philipov D., Testa M.R., Attitudes, norms and perceived behavioural control: Explaining fertility intentions in Bulgaria, "European Journal of Population" 2009; 25 (4): 439-465.

7. Billingsley S., Ferrarini T., Family policy and fertility intentions in 21 European countries, "Journal of Marriage and Family” 2014; 76 (2): 428-445.

8. Dommermuth L., Klobas J., Lappegard T., Now or later? The theory of planned behavior and timing of fertility intentions, "Advances in Life Course Research" 2011; 16 (1): 42-53.

9. Vignoli D., Rinesi F., Mussino E., A home to plan the first child? Fertility intentions and housing conditions in Italy, "Population, Space, and Place" 2013; 19: 60-71.

10. Frątczak E., Ptak-Chmielewska A., The interplay of fertility intentions, female employment and work-life balance policies in contemporary Poland: Can gender equity, preference, and social capital theories provide a better insight?', in: Oláh L.S., Frątczak E. (eds.), Childbearing, Women's Employment and Work-Life Balance Policies in Contemporary Europe, Palgrave Macmillan, Hampshire 2013.

11. Mynarska M., Styrc M., Preferencje i ograniczenia. Czynniki determinujace intencje posiadania pierwszego i drugiego dziecka, in: Matysiak A. (ed.), Nowe wzorce formowania i rozwoju rodziny $w$ Polsce. Przyczyny oraz wplyw na zadowolenie z życia, Scholar, Warszawa 2014: 54-76.

12. Begall K., Mills M., The impact of subjective work control, job strain and work-family conflict on fertility intentions: A European comparison, "European Journal of Population" 2011; 27 (4): 433-456.

13. Modena F., Sabatini F., I would if I could: Precarious employment and childbearing intentions in Italy, "Review of Economics of the Household" 2012; 10 (1): 77-97.

14. Regnier-Loilier A., Vignoli D., Fertility intentions and obstacles to their realization in France and Italy, "Population" (English edition) 2011; 66 (2): 361-389.
15. Cavalli L., Rosina A., An analysis of reproductive intentions of Italian couples, "Population Review" 2011; 50 (1): 21-39.

16. Hayford S.R., Morgan P.D., Religiosity and fertility in the United States: The role of fertility intentions, "Social Forces" 2008; 86 (3): 1163-1188.

17. Miettinen A., Basten S., Rotkirch A., Gender equality and fertility intentions revisited: Evidence from Finland, "Demographic Research" 2011; 24: 469-495.

18. Ajzen I., The theory of planned behaviour, "Organizational Behaviour and Human Decision Processes" 1991; 50 (2): 179-211.

19. Miller W. B., Childbearing motivations, desires, and intentions: A theoretical framework, "Genetic Social and General Psychology Monographs" 2011; 120 (2): 223-258.

20. Sobotka T., Testa M.R., Attitudes and intentions towards childlessness in Europe, in: Höhn C., Avramov D., Kotowska I.E. (eds.), People, Population Change and Policies. Lessons from the Population Policy Acceptance Study, Springer, Netherlands, 2008: 203-244.

21. Finocchario-Kessler S., Sweat M.D., Dariotis J.K., Trent M.E., Kerrigan D.L., Keller J. M., Anderson J.R., Understanding high fertility desires and intentions among a sample of urban women living with HIV in the United States, "AIDS and Behaviour" 2010; 14 (5): 1106-1114.

22. Hayford S.R., Agadjanian V., Luz L., Now or never: Perceived HIV status and fertility intentions in rural Mozambique, "Studies on Family Planning" 2012; 43 (3): 191-199.

23. Loutfy M.R., Hart T.A., Mohammed S.S., Su D., Ralph E.D., Walmsley, S.L. for the Ontario H. I. V. F. R. T., Fertility desires and intentions of HIV-positive women of reproductive age in Ontario, Canada: A cross-sectional study, "PLoS One" 2009; 4 (12): e7925.

24. Roe A.H., Traxler S.A., Hadjiliadis D., Sammel M.D., Schreiber C.A., Contraceptive choices and preferences in a cohort of women with cystic fibrosis, "Respiratory Medicine" 2016; 121: 1-3.

25. Shandra C.L., Hogan D.P., Short S.E., Planning for motherhood: Fertility attitudes, desires andintentions among women with disabilities, "Perspectives on Sexual and Reproductive Health" 2014; 46 (4): 203-210.

26. Wojtyniak B., Umieralność kobiet $w$ wieku 15-49 lat, in: Niemiec T. (ed.), Zdrowie kobiet $w$ wieku prokreacyjnym 15-49. Polska 2006, Program Narodów Zjednoczonych ds. Rozwoju (UNDP), Warszawa 2007.

27. Central Statistical Office, Stan zdrowia ludności Polski w 2004 r., GUS, Warszawa 2006.

28. Central Statistical Office, Stan zdrowia ludności Polski w 2009 r., GUS, Warszawa 2011.

29. Central Statistical Office, Stan zdrowia ludności Polski w 2014 r., GUS, Warszawa 2016.

30. Wróblewska W., Determinants of women's health status in Poland in transition to market economy, "Social Science and Medicine" 2002; 54 (5): 707-726.

31. Wróblewska W., Wróblewski Ł., Jakość życia ludności uwarunkowana stanem zdrowia, "Wiadomości Statystyczne" 2007; 6.

32. Mynarska M., Matysiak A., Rybińska A., Którędy do bezdzietności? Analiza ścieżek życia kobiet, które nigdy nie zostaty matkami, in: Matysiak A. (ed.), Nowe wzorce for- 
mowania i rozwoju rodziny w Polsce. Przyczyny oraz wplyw na zadowolenie z życia, Scholar, Warszawa 2014: 105-131.

33. Vikat A., Speder Z., Beets G., Billari F.C., Buhler C., Desesquelles A., Solaz A., Generations and Gender Survey (GGS): Towards a better understanding of relationships and processes in the life course, "Demographic Research" 2007; 17: 389-439.

34. Kotowska I., Jóźwiak J., Panelowe badanie przemian relacji między pokoleniami, w rodzinie oraz między kobietami i mężczyznami: generacje, rodziny i pleć kulturowaGGS-PL', "Studia Demograficzne" 2011; 1 (159): 99-106.

35. Mynarska M., Kto planuje mieć dzieci w Polsce do 2015 roku?, "Studia Demograficzne" 2011; 1 (159): 75-98.

36. Hosmer D.W., Lemeshow S., Applied Logistic Regression, John Wiley and Sons, Inc., Canada 2000.

37. Case A., Fertig A., Paxson C., The lasting impact of childhood health and circumstance, "Journal of Health Economics" 2005; 24 (2): 365-389.

38. Haas S.A., Health selection and the process of social stratification: The effect of childhood health on socioeconomic attainment, "Journal of Health and Social Behaviour" 2006; 47 (4): 339-354.

39. Palloni A., Milesi C., White R.G., Turner A., Early childhood health, reproduction of economic inequalities and the persistence of health and mortality differentials, "Social and Science Medicine" 2009; 68: 1574-1582.

40. Central Statistical Office, Podstawowe informacje o rozwoju demograficznym Polski do 2014 roku, GUS, Warszawa 2015.
41. Gustafsson S., Optimal age at motherhood. Theoretical and empirical considerations on postponement of maternity in Europe, "Journal of Population Economics" 2001; 14 (2): 225-247.

42. Schmidt L., Sobotka T., Bentzen J.G., Nyboe Andersen A., Demographic and medical consequences of the postponement of parenthood, "Human Reproduction Update" 2012; 18 (1): 29-43.

43. Wróblewska W., Zdrowie i spoteczne nierówności w stanie zdrowia (Health and social inequalities in health), in: Panek T. (ed.), Statystyka spoteczna, PWN, Warszawa 2014.

44. World Health Organization (1946), Preamble to the Constitution of the World Health Organization as Adopted by the International Health Conference, New York, 19-22 June, 1946; signed on 22 July 1946 by the representatives of 61 States, Official Records of the World Health Organization, No. 2, p. 100, and entered into force on 7 April 1948.

\section{Data sources}

Eurostat, 2016, demo_mlexpec, http://ec.europa.eu/eurostat/ data/database; accessed: 15.11.2016.

Eurostat, 2011, EHSIS data, hlth_dp040, http://ec.europa.eu/ eurostat/data/database; accessed: 15.11.2016.

Eurostat, 2012, LFS data, hlth_dpeh005, http://ec.europa.eu/ eurostat/data/database; accessed: 15.11.2016.

Proofreading: Małgorzata Kierska 